\title{
ВЕРБАЛІЗАЦІЯ КОНЦЕПТУ СВЯТО В ЕПІСТОЛЯРНІЙ ПОВЕДІНЦІ ЛЕСІ УКРАЇНКИ
}

\author{
СВІТЛАНА БОГДАН \\ Волинський національний університет імені Лесі Українки, Луцьк - Україна \\ WERBALIZACJA KONCEPTU ŚWIĘTO W LISTACH ŁESI UKRAINKI \\ SWITLANA BOHDAN \\ Wołyński Państwowy Uniwersytet imienia Łesi Ukrainki, Łuck — Ukraina \\ STRESZCZENIE. W artykule rozpatrzono werbalizację konceptu święto w systemie \\ zachowania epistolarnego Łesi Ukrainki, jego dyferencjalne cechy komunikatywno- \\ pragmatyczne; podstawowa uwaga została skupiona na dominantach strukturalno- \\ semantycznych święta: powinszowaniach i prezentach.
}

\section{VERBALIZATION OF THE CONCEPT SVIATO IN EPISTOLARY BEHAVIOUR OF LESYA UKRAINKA}

\author{
SVITLANA BOGDAN \\ Volyn' Lesya Ukrainka National University, Luts'k — Ukraine
}

ABSRACT. The article focuses on the verbalization of the concept sviato in the system of epistolary behaviour of Lesya Ukrainka, its communicative-pragmatic features; the main attention has been paid to structural-semantic dominants of the process of celebration: congratulations and presents.

$\mathrm{T}$

радиційно комунікативна поведінка людини може бути диференційована за різними функціональними ознаками. Однією із вагомих розрізнювальних ознак поведінки мовців є протиставлення за дихотомією свято будень, що передбачає наявність як спільних, так і особливих рис. Важливим чинником, що формує специфіку індивідуальної святкової поведінки комуніканта, $\epsilon$ екстралінгвальний показник: особистісне ставлення мовця до свят і процесу святкування.

Свята й святкування як елемент комунікативної поведінки Лесі Українки не були об'єктом спеціального дослідження, незважаючи на те, що в родині Косачів, як відомо, особливу увагу приділяли відзначенню як основних релігійних (рокових) свят (Різдва, Великодня), так і світських (Нового року, роковин Шевченка, днів народження членів родини та друзів). Одним із джерел такого вивчення правомірно можуть слугувати епістолярні тексти, завдяки яким можна окреслити передусім ставлення Лесі Українки до цього компонента людської життєдіяльності, а також частково реконструювати типову святкову поведінку всієї Косачівської родини, їхніх друзів та іiі індивідуальну.

Насамперед зауважимо, що найуживанішою номінацією цього часового відтинку - урочистих днів людського життя — в епістолярії Лесі Українки слугує лексема свято, менш продуктивна - празник, рідко вживана - святки (очевидно, передусім із огляду на вужче лексичне значення). Номінація свято в українській мові традиційно визначає „день або дні, коли урочисто відзначають 
видатні події, знаменні дати” або „відзначений звичаєм або церквою день на честь якої-небудь події чи святого"2. У листах Лесі Українки вона вживана найчастіше саме в таких значеннях, порівн.: „Дядько був надзвичайно зворушений, читаючи про ювілейну справу. Та справді не міг він не бачити, щзо його ювілей був чимось іншим для нас усіх, ніж звичайні ювілеї з тречними промовами. Се справді було свято (тут і далі вирізнення мої. - С. Б.) свідомої себе України"з (до М. І. Павлика, 23 лютого 1895 р., Софія) і „На свята ми додому не їздли, бо ми собі не робили різдвяних вакацій, а вчились, тільки три дні святкували. Мій Олег статкує!'”4 (до М. П. Драгоманова, 17 січня 1894 р., Київ). Хоч спорадично фіксоване використання цієї лексеми в значенні „важлива, радісна, приємна подія, а також день, коли вона сталася"5. Зауважмо, що в Словнику Б. Грінченка ця номінація відсутня, натомість репрезентовано композит святдень для найменування святкового дня ${ }^{6}$. Демінутив святонько вжито лише один раз у листі до Агатангела Кримського: „Нащуо думати про катастрофи, дорогий товаришу? Над усіма нами вони висять, та, на щзастя, ми не знаємо, коли вони впадуть. От я запрошую Вас у гостину, а чи одміряно мені стільки життя, щуоб я могла „дочекатися того святонька”?”7 (до А. Ю. Кримського, 27 жовтня 1911 р., Цулукідзе).

Атрибутивна ознака, похідна від свято, репрезентована синонімічними лексемами святковий, святочний (словник подає іï̈ з ремаркою рідко ${ }^{8}$ ) і святечний. Процесуальна дія передана лексемами святкування й святкувати. Лексема святки узвичаєно означає „святкову пору від Різдва до Водохрещів (у православних)" або „святкові дні (перев. великодні)",

Словник Б. Грінченка подає слово празник як повноцінне найменування святкової днини та фіксує похідну зменшувальну номінацію празничок ${ }^{10}$, хоч одинадцятитомний Словник украӥнської мови кваліфікує цю лексему як розмовний варіант до свята та застаріле найменування „дня чи днів, певним чином відзначуваних звичаєм або церквою""1. Відповідно, всі похідні деривати празниковий, празничний, празниково, празнично, празникування, празникувати, празнувати означено як розмовні еквіваленти словотвірного ряду від свято ${ }^{12}$. Закономірно припустити, що на кінець XIX - поч. XX ст. ці лексеми, навпаки, посідали центральну, а не периферійну позицію в лексичній парадигмі нашої мови та індивідуальній мовній практиці, що й пояснює гармонійне функціонування обох типів найменувань в епістолярії Лесі Українки.

Спостережено однак, що Леся Українка використовувала лексеми празник, празникування здебільшого в листах до бабусі (напр.: „Поздравляю Вас з празником, бажаю Вам здоров'я і всього найкращого, щзоб нам з Вами знов

\footnotetext{
${ }^{1}$ Словник української мови, в 11 тт., Київ 1978, т. 9, с. 104.

2 Там само, с. 105.

3 Леся Українка, Зібр. творів, у 12 тт., Київ 1975-1979, т. 10, с. 282.

${ }^{4}$ Там само, с. 203.

${ }^{5}$ Там само, т. 9, с. 105.

${ }^{6}$ Словарь украӥнської мови, в 4 тт., упоряд. 3 додатк. власн. матер. Б. Грінченко, Київ 1996,

7 Леся Українка, Зазн. джерело, т. 12, с. 372.

${ }^{8}$ Словник украӥнської мови, в 11 тт., Київ 1978, т. 9, с. 105.

${ }^{9}$ Там само, с. 104.

${ }^{10}$ Словарь української мови, в 4 тт., упоряд. $з$ додатк. власн. матер. Б. Грінченко, Київ 1996,

${ }^{11}$ Словник української мови, в 11 тт., Київ 1976, т. 7, с. 512.

${ }^{12}$ Там само, с. 512.
} T. 4 , c. 111 . т. 3 , c. 401 . 
провести літо так, як сей рік, - весело та щзасливо”'з (до Є. І. Драгоманової, 3 січня 1894 р., Київ), спорадично - до М. П. Драгоманова, матері й сестри Ольги, тобто це передусім ознака іiі ранньої епістолярної поведінки. I навпаки, лексеми свято, святкування позначені універсальністю функціонування й не диференційовані типом адресата.

Насамперед зауважмо, що для Лесі Українки свято (свята) - празник (празники) (рідше порівняно з попередніми лексемами) значною мірою слугують певною часовою межею й точкою відліку: події в Косачівській родині відбуваються в трьох основних вимірах (відповідно до узвичаєного часового відліку українців, збереженого частково й дотепер) - до свята (перед святами) / перед празником, на свята / -ах (святами) / на празник, після свят (по святах) (до речі, саме завдяки такій епістолярній інформації дослідникам удалося датувати чимало Лесиних листів), напр.: „В Одесу я після свят вже не поїду, а хіба або на Великдень, або як вертатиму додому в апрілі чи в маї, еrgo вистава не про мене писана"14 (до О. П. Косач (сестри), 18 січня 1898 р., Ялта); „Плаття мені вже готово, я вже його й надівала разів зо два, дуже добре вийлло. Оксанине щее не готово, але до свят пошиється. Казала модистка, щуо на гроші зачекає до свят"15 (до О. П. Косач, 29 грудня 1898 р., Київ); „Ще й писали ми тобі мало святами. Мені ти, запевне, сього за зле не візьмеш, бо се навіть краще було, щуо я не писала, може, й тепер щуе слід би помовчати, бо, либонь, з листа неврастенія скаче - правда?"16 (до О. П. Косач (сестри), 26, 27 квітня 1900 р., Київ); „Але я перед святами саме вибиралася з Києва - додому приїхали ми в середині страсного тижня, - а на свята ще не ввійила настільки в колію життя, щуоб засісти за писання листів"'17 (до А. С. Макарової, 14 травня 1894 р., Колодяжне).

Крім узвичаєного літературного варіанта на свято, Леся Українка вживала також говірковий про свято ( „Я буваю частіше тільки у дядини та ще у Стар[ицьких] (там тепер Зіна - скульпторка, дуже вона мені подобалась), а в інших так „про свято”"18 (до О. П. Косач (сестри) 28 листопада 1899 р., Київ), що активізований, до речі, в мовленні поліщуків дотепер.

Традиційне сприйняття свята, празника, очевидно, актуалізує передусім первинне значення цих лексем: „час, вільний від роботи, бездіяльний”19. 3 іншого боку, - асоціативно вербалізує цілу низку лексико-семантичних ознак, співвіднесених із ними: гості, гостювання, гостити, розваги, подарунки, привітання, виконання певних обрядів і обрядодій. Інакше кажучи, будь-яке святкування передбачає реалізацію різних елементів етикетного дискурсу й етикетної поведінки. До найуживаніших і потенційно передбачуваних закономірно належать різні форми привітань, про що йтиметься далі.

Сприйняття Лесею Українкою свят значною мірою корельовано 3 типологічним для української ментальності, щоправда, з виразним переважанням нейтральних, а почасти навіть негативних емоцій, про що свідчать неодноразові коментарі в листах до різних адресатів. Святковий період завжди викликає прогнозовані традиційні епістолярні контексти, неодмінний компонент яких -

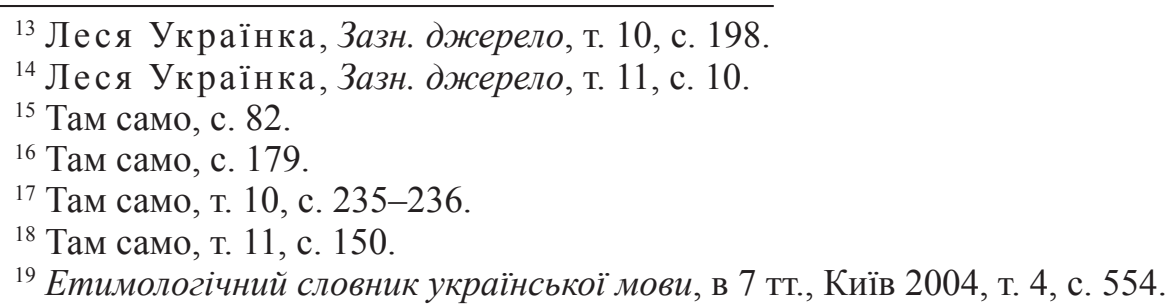


стереотипні лексеми й словосполучення: вештання гостей (,Як ти пишеш, щуо за гостями на святах двері не зачинялись, то навряд, щзоб і дома вам щцирий відпочинок був. Та вже з сього ніхто не винен, не виганяти ж людей (до О. П. Косач (сестри), 25 січня 1904 р., Тбілісі), візити (,На перший день, як завжди, цілий хаос візитів і всякого вештання",21 (до О. П. Косач (сестри), 26, 27 квітня 1900 р., Київ)), шарварок (, Папа просить пробачення, щзо за зборами в дорогу, а раніш за святечним шарварком не написав тобі, може, напише десь із Черкас 22 (до О. П. Косач (сестри), 26, 27 квітня 1900 р., Київ)), нудьга, метушня, клопоти (власне святкові й передсвяткові) (, Наші старші тим часом виїздил: спочатку їздив у Колодяжне папа, а далі, на страсному тижні, мама, отже, мені прийшлось і передсвятковий клопіт взяти на себе, правда, остатніх два дні мені трохи помагала Оксана, але я не хотіла багато ï̈ помочі, бо вона ще тоді не оправилась як слід по своїй слабості. Ходила я і на базар, пекла мазурки, иила, прибирала, гляділа Дори, приймала навіть гостей при всьому том: приїздив Френкель і Серг[ій] Кост[янтинович], а крім того, заходили різні чоловіки, вигнані жінками з дому на страсному тижні „за ненадобностью”. Межи всім тим їздана Крещуатик, вставання вночі до Дори i m. $i$. не лишали й хвилини вільного часу"'23 (до О. П. Косач (сестри), 26, 27 квітня 1900 р., Київ)), багато роботи (,На свята якось чудно час зіходив - не то щзоб було мені весело, а шпорталась і метушилась чимало, то ялинку дітям убирала, то живі картини вряджала, і так воно здавалось, щзо роботи багато було”"24 (до Л. М. Драгоманової, 22 січня 1893 р., Колодяжне), прийом гостей, спілкування (,Різдвяними святками дуже сильно боліло, бо я таки трохи засиджувалася з добрими людьми то за балачками, то за якою-небудь грою знічев 'я” 25 (до О. П. Косач (сестри), 31 січня, 1 лютого 1910 р., Хельван). Це все нерідко не просто втомлювало, а й виснажувало Лесю Українку: „Думала вже на свята взятись до писання листів і уліт, ,но не тут-то было”; вже в першу великодню ніч мусила я сама себе одливати водою, бо Оксана і Дора спали, а більи нікого дома не було (мама ще не приїхала була, а папа і Микось по иерквах ходили)"'26 (до О. П. Косач (сестри), 26, 27 квітня 1900 р., Київ).

Симптоматичний також для розуміння сприйняття Лесею Українкою процесу святкування загалом інтекстовий фрагмент - iї переклад пророчих книг: „Що для мене ся безліч дарів? / Досить ви попалили ягнят, баранів, / Мені кров кіз, телят вже немила. / Ви до мене не йдіть, хто від вас вимагає сього? / Не приходьте ви більше до двору мого, / Бридкі пахощуі ваші й кадила! / Ваших свят, і субот, і великого дня не терплю! / Святкування, постів, празників не люблю, / Ненавидить душа моя того!'” Iсаії I, с. 2-3, 11-1827 (до М. П. Драгоманова, 27 жовтня 1892 р., Колодяжне). Імовірно, що цей контекст наведено невипадково: змістово він міг бути суголосним їі власним поглядам. Тим паче, що підстави саме для таких припущень цілком реальні: Леся Українка не сприймала передусім абсолютизацій і гіпертрофувань, зокрема тривалих багатоденних святкувань, а також культивування певних обрядів: „Ще злить

\footnotetext{
20 Леся Українка, Зазн. джерело, т. 12, с. 101-102.

${ }^{21}$ Там само, т. 11, с. 176.

22 Там само, с. 179.

23 Леся Українка, Зазн. джерело, т. 11, с. 176.

24 Там само, т. 10 , с. 145.

25 Там само, т. 12 , с. 300.

26 Там само, т. 11, с. 176.

27 Там само, т. 10 , с. 141.
} 
мене сей культ празникування, все одно як культ вінчання у людей, щзо нібито не вірять в те, во ім'я чого установлені і свята, і обряди" 28 (до О. П. Косач (сестри), 29 грудня 1902 р., Сан-Ремо).

Незрозумілі й чужі для неї були також почасти материнські нівелювання особистісних бажань дітей щодо святкувань: „Оксана згадує в листі до мене, щзо ти противишся сій ї̈ подорожі до Києва, але щзо вона ,не може не їхаmи" (kurz und gut! (коротко і ясно (нім.), щзо хотіла, правда, остатись на перші дні свят в Запрудді ради ялинки для запрудських дітей, але мама (вона ж була в Запрудді) „обидилась” за такий замір, отже, „не варт сваритись із-за пустяків”, і Оксана вже поїде празникувати в Київ. „ІІторія нас учить, щуо вона нічого не учить!..” Знов ті самі ,обиди”, замість нормального відношення до здоров'я $і$ волі своєї дитини!"29 (до О. П. Косач (сестри), 29 грудня 1902 р., Сан-Ремо).

Прикрим моментом святкового побуту, за неодноразовим зізнанням Лесі Українки, були також непередбачувані грошові витрати - розтрати (в їі слововжитку), що спонукали до специфічних епістолярних звітів батькам: „Cnacuбі тобі за гроші $i$ за те, щзо не лаєш нас за святочну розтрату, хоч я знаю, щзо тобі се мусило бути дуже неприятно. Ти просиш написати наш ,, бюджет”, то ось він як виходить" (далі в листі подано детальну фінансову інформацію видатків на свято)" ${ }^{\prime 30}$ (до П. А. Косача, середина січня 1894 р., Київ).

Позитивним пунктом святкувань для Лесі Українки, поза сумнівом, можна вважати можливість відвідувати театри („Святками я собі трохи балувалась, ходила з „свойми дітьми” - Лілею та Тосею (син тьоті Саші в гостях y нас mепер) - в театр тощзо"з1 (до О. П. Косач, 17 січня 1894 р., Київ); „на свята ми пішли кілька раз в театр"з2 (до О. П. Косач (матері), 19 січня 1894 р., Київ); „В театр, в оперу на „Демона”, „,Фауста”, „Свг[енія] Онєгіна” $i$ „Паяџи” наші ходили святами чотири рази, двічі зо мною, а двічі з Мишею, окрім того, по Новому році були ми щуе на „Плодах просвещзения”, та Тося з Лілею $i$ з товаришами ходили на „Ріголетто”"з3 (до О. П. Косач, 23 січня 1894 р., Київ) й концерти (,На празники я нікуди не ходила, бо іще слаба, а тепер позавчора ранком справляли Шевченкові роковини, то я ходила, Миша і Ліля, і ми там читали стихи. Давніше я ходила на два концерти; на перший ходили: я, мама і Миша, а на другий тільки я і мама"з4 (до Є. І. Драгоманової, 11 березня 1883 р., Київ).

Неодмінний і цілком умотивований компонент епістолярних текстів Лесі Українки - опис святкових традицій інших народів, зокрема італійців (,Cвяm тут менше, ніж у нас, але зате, напр [иклад], позавчора ні з того ні з сього всіх розпустили з 10 г[одини] рано, через те щзо „сьогодні гонки”"'з5 (до І. П. Косач, 15 березня 1902 р., Сан-Ремо); „Перед св[ятим] вечором вдень грала музика в саду міському, а в изерквах були вряджені вертепи з діячами - теракотовими фігурами: Madonna, San Giuseppe, — pastori etc. (Мадонна, святий Йосиф, пастирі і m. n. (італ.)), всі дуже італьянізовані, а збоку і в аггіеге (позаду (франц.))

\footnotetext{
${ }^{28}$ Там само, т. 11, c. 376 .

${ }^{29}$ Там само, с. 375-376.

30 Леся Українка, Зазн. джерело, т. 10, с. 199.

31 Там само, с. 202.

32 Там само, с. 204.

33 Там само, с. 206.

34 Там само, с. 13.

35 Там само, т. 11, с. 333.
} 
сцені вже й просто італьянські типи дівчат з мандолінами i m. $i$. Я бачила те вдень приготоване для вечірньої відправи (тільки Gеsи bambino (маленького Ісуса (італ.)) щее не було), а ввечері не бачила, було холодно і дощц накрапав, так щзо не можна було виходити мені. Цілий вечір по вулицях їздили оркестри всякої музики, витинали дуже веселі марші і слонялись перед більшими віллами для серенад"36 (до О. П. Косач (матері), 28 грудня 1901 р., Сан-Ремо). У листах знаходимо детальні фіксації кулінарних Різдвяних традицій. Найдужче іiі вразила зокрема „квіткова” різдвяна традиція італійців: „Оџе ж тут вже й різдво минуло... От який тут святий вечір $і$ коляди. Замість куті був якийсь особливий пудинг (либонь, теж обрядовий), обложений букетами фіалок. Другого дня (1-й день Різдва) квіток було у нас сила! Bci fournisseurs (постачальники (франи.)) понаносили квіток при своїх продуктах. Тут же все присилають з базару самі продавці, а кухарка тільки ходить вибирати, так ото й прислали м'ясо з трояндами, молоко з геліотропом і $m$. д. Навіть хлопець-візник, щзо служить у Садовських, приніс своїи господині величезного букета pеr buоnе feste Natalizie (на добре різдвяне свято (італ.)), а кухарка прибори за столом квітками убрала. Кажуть, таке саме має бути й на Новий рік. Квіток тут взагалі не жалують, бо на їх тут „не голодні”. Навіть на бульварах нікому не боронять зривати рожі, скільки хто хоче, бо з тих рож тут живоплоти роблять i вони цвітуть цілий рік"з7 (до О. П. Косач (матері), 28 грудня 1901 р., СанРемо). Під впливом цієї традиції вона надіслала „пуделко живих квіток” рідним (батькам, сестрі Ользі й Раді) з Італії: „Я вам усім (родині) посилаю завтра поздоровлення новорічне на італьянський лад: пуделечко живих квіток. Як принесуть повістку, то не гайтесь отримати з пошти, щцоб квітки не пов'яли, а скоріш, щзо принесуть посилку одразу додому, бо то посилається експресом, на правах „заказного лист”з8 (до П. А. Косача і О. П. Косач (матері), 7 січня 1903 р., Сан-Ремо). Але вся ця екзотика не могла замінити ӥй свято в родинному колі (потреба в якому активізувалася з роками, перебуваючи найчастіше в свята поза родиною), про що вона з зачаєною (імпліцитно актуалізованою) тугою повідомляє мамі на завершення грунтовного опису цих традицій: „Як то там y вас Різдво буде? Либонь, з снігом-морозом $i$ без квіток. А все жс воліла б я бути на Різдво в Києві' 39 (до О. П. Косач (матері), 28 грудня 1901 р., СанРемо). І це, зауважмо, незважаючи на неодноразові зізнання про втомливість свят. Як ніхто інший із родини, Леся Українка знала ціну святкового родинного мікрокосмосу, вдаючись до своєрідного прийому літоти в одному з листів до сестри Ольги,: „... я трохи знаю, що то таке - свята на чужині або між чужсим людьми"”40 (до О. П. Косач (сестри), 26, 27 квітня 1900 р., Київ).

У листі до сестри Ольги 13 березня 1900 року з Тарту вона описує особливості Дня покути в лютеран: „, Сьогодні велике лютеранське свято Bussetag i в цзеркві лютер [анській] буде великий релігіозний конщерт на органі з акомпанементом оркестру, гратимуть Баха, Генделя $i$ m. $i$., я такого не чула щуе $i$ взагалі дуже люблю орган, отже, хочеться послухати"41.

Зацікавленість специфікою зимових святкувань у Болгарії засвідчує лист до Михайла Драгоманова від 5 січня 1890 року з Колодяжного: ,, Однак годі вже

\footnotetext{
${ }^{36}$ Там само, с. 299.

37 Там само, с. 299.

38 Леся Українка, Зазн. джерело, т. 12, с. 9.

${ }^{39}$ Там само, т. 11, с. 299.

${ }^{40}$ Там само, с. 179.

${ }^{41}$ Там само, с. 169.
} 
мені просторікувати - задля святого вечора варто б вже й перу пільгу дати. Хочу тільки де про щзо Вас запитати: чи співають у Болгарї̈ колядки і чи похожі вони на украӥнські? Як там люди обходять Різдво?"'42.

Особливо незатишно почувалася вона в святкові дні на чужині. Варто лишень нагадати рядки їі листа з Ялти до сестри Ольги в Різдвяні дні 1908 року: „Пробач, щуо у мене прокинувся досить гіркий $і$ зовсім уже не празниковий тон, але я не почуваю ніякого свята $і$ не можу вмовити себе, щзо воно $\epsilon-$ wо?.. "43 (до О. П. Косач (сестри), 7 січня 1908 р., Ялта).

Перебуваючи в розлуці з родиною, розраду в свята приносили також листи й, що цілком закономірно, позитивна інформація в них, порівн.: „, Напиши мені, мамочко моя, лагідніший лист - я бачу, щуо ти щзе сердишся на мене, - а то мені свята будуть втрос сумніші, коли я не матиму доброго слова від тебе"44 (до О. П. Косач, 30 грудня 1893 р., Київ). Власне тому вона неодноразово спонукала братів і сестер до активного спілкування: „Прошу писати мені на свята i других до того заохочувать, бо хоч я і не дуже буду скучать, ,, тем не менее, однако же, все-таки..." ${ }^{45}$ (до О. П. Косач (сестри), 27 грудня 1897 р., Ялта).

Нерідко, однак, свято додавало їй лише втоми й апатії ( „Я лінувалась иілі свята і сливе нічого не робила, чогось було апатія найшла, може, через дош невсипущий, щзо вже з тиждень ллє. Тепер знов status qио вернувся, $і$ я вже більи не писатиму одного листа по два дні" ${ }^{\prime 6}$ (до М. І. Павлика, 19 квітня 1895 p., Софія); , Любії мої! Все збираюся написати довгого листа і все ніяк не зберуся, почасти через всякі дрібні околочності, а більше через лінощі (треба б було хоч сим відсвяткувати Великдень ${ }^{47}$ (до родини Косачів, 12 травня 1907р., Ялта) й вносило певну аритмію в робочий темп (,...на свята $і$ зовсім нічого не можна було робити, спочатку катастрофа з папою (вивихнув було собі руку й два тижні пробув у пов'язиі), а потім візити безконечні, приїзд Миші і m. n. вибили мене з колії; насилу прийшло життя в нормальний стан, як тут знов Людине весілля, мамине нездоров'я, походи на Хрещзатик знов перекинули все догори дном" "48 (до Л. М. Драгоманової, 10 лютого 1896 р., Київ). Очевидно, саме через ці причини з ініціативи Лесі Українки іноді вносилися корективи в перебіг святкування: „Сього року я теж мало свят бачила, бо ми з знайомою „з принципу” скоротили ad minimum всю празникову процедуру, а наші знайомі теж „з приниипу” не бігали до нас з празниковими візитами. I вийило прекрасно"49 (до О. П. Косач (сестри), 22 квітня 1904 р., Тбілісі). Прагненням позбутися небажаного емоційного стану 'скуки' й 'нудоти', органічно поєднаних, на іiі переконання”, зі святом був мотивований зокрема й „проект” подорожі на Різдвяні свята 1898 року в Одесу до приятельки Маргарити Комарової. Саме в листах цього передсвяткового періоду, зокрема до матері 25, 26 грудня з Ялти, вона висловлює своє ставлення до свят загалом: „Поїхати, скажу правду, я хотіла б- перспектива страшенної нудоти в Ялті на свята лякає не тільки мене, але навіть моїх немногих знайомих за мене, їм, бачиш ти, ,вчуже” сумно. Та все иуе залежить від погоди, від стану здоров'я $і$ m. $п$. причин. Я не придаю великого

\footnotetext{
42 Там само, т. 10 , с. 46.

43 Там само, т. 12 , с. 222.

${ }^{44}$ Там само, т. 10 , с. 197.

45 Там само, с. 419.

46 Там само, с. 298.

47 Леся Українка, Зазн. джерело, т. 12, с. 209.

48 Tам само, т. 10 , с. 335-336.

49 Там само, т. 12 , с. 105.
} 
значення „святам”, але давно замітила, щео під час них буває щее скучніше, ніэе в будні (себто коли взагалі не нудно), бо роботи стає менше, а вид людей в празниковому настрої наводить не то сум, не то заздрощі. Врешті, невважаючи на се, може, й тут прийдеться просвяткувати"'50 (до О. П. Косач (матеpi), 25, 26 грудня 1897 р., Ялта). Щоправда, через день, пишучи листа сестрі Ользі, Леся Українка визнала такий емоційний стан „хвильовим”, а його словесне потрактування — „малодушієм”: „Щодо тої „, перспективи страшенної нудоти на свята і пролетаріатської самотині", про яку я писала мамі в остатньому листі, то все иее я, „по здравому размышлению” на дозвіллі вважаю за малодушіе, про яке і згадувати сором, $і$ прошу дивитись на нього, як на хвильовий настрій, не вартий серйозної уваги" "51 (до О. П. Косач (сестри), 27 грудня 1897 р., Ялта). Більше того, вона вважала, що від самої людини значною мірою має залежати ії настрій: „, Скучати чи не скучати се в великій мірі залежить від волі самої людини, і коли вона дуже дає собі в сьому волю, то, значить, сама й винна, коли ій погано”.

Водночас Леся Українка не заперечувала, що позитивний вектор свята визначається також певними соціальними передумовами. Серед найбажаніших вона здебільшого називала приїзд у гості когось із родини, якщо доводилося зустрічати свято поза рідною оселею. Варто лишень згадати гостювання сестер

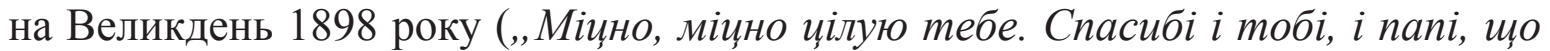
ради мене пустили з дому на свята моїх гусів ..." 52 (до О. П. Косач (матері), 11 квітня 1898 р., Ялта); „Ще раз дякую тобі i папі, щзо пустили гусів до мене, а то не було б мені свято святом" "53 (до О. П. Косач (матері), 22 квітня 1898 р., Ялта), а також очікування маминого приїзду на Різдво в Ялту 1998 року). Водночас варто зауважити, що такі бажані для неї візити вона за жодних умов не хотіла приймати як ,жертву” родини в ім'я іiї благополуччя: „Я боюсь, щุо мама через те хоче спішити з виїздом до мене, щзоб утримати мене від сеї прикрої для неї подорожі, але скажи їй, що втримувать мене не треба, я сама не поїду. Звичайно, я була б несказанно рада побачити маму на свята, але жс я не хочу і не маю права вимагати жертв, отже, не раджу їй їхать через ті самі причини, через які сама не поїду в Одесу" "54 (до О. П. Косач (сестри), 27 грудня 1897 р., Ялта).

Очевидно, через особливу вимогливість до себе Леся Українка неодноразово акцентувала увагу в листах до родини на брак поздоровного таланту й відповідного стилю: „, Одкриток же тим часом нікому не послала, бо не зібралась вибрати і купити якихось порядних раніше своєї простуди, а ие вже завтра вийду на місто, то куплю. Прошу Микося $і$ Дору вибачити мені за негречність. Та то відомо, щчо я і ніколи не тямила „поздоровного” стилю, а сей рік i надто..." "55 (до О. П. Косач (сестри), 25 січня 1904 р., Тбілісі). Мабуть, саме такі пресупозитивні передумови формували очевидну аскетичність і лаконічність їі побажальних текстів, напр.: „, ... а тим часом з Новим роком, бо він уже mym $\epsilon c m b " 56$ (до сестри Ольги, 2 січня 1902 року, Сан-Ремо). Не менш важливим чинником можна вважати також той факт, що вона не вірила, за їі зізнанням,

\footnotetext{
50 Там само, т. 10 , с. 415 .

51 Там само, с. 418.

52 Там само, т. 11 , с. 40.

53 Там само, с. 44.

54 Леся Українка, Зазн. джерело, т. 10, с. 418.

55 Там само, т. 12 , с. 101 .

56 Там само, т. 11 , с. 305.
} 
у силу побажань, передусім новорічних: очевидно, з огляду на потенційні звукові асоціації рік - року (тобто, фатуму) (,Дорогий пане товаришу, коли Ви дозволяєте так себе назвати, то я з охотою готова. Слова „з Новим роком” по якійсь давній, привичній асоиіації ідей наводять на мене смуток... Тому я прошу у Вас дозволу не казати їх тепер Вам, - не тим, щуо я не хочу Вас поздоровити, а тим, щзо не дається мені той стиль, та й... не дуюсе я вірю в силу новорічних бажань" "57 (до I. Я. Франка, 13, 14 січня 1903 р., Сан-Ремо). Ще більшою мірою вона упереджено ставилася до побажальних слів, якщо вони стосувалися неї самої: „Поздоровляю тебе і Михалів з святками і Новим роком, чей же, той новий буде для вас милостивіший від старого. А от для мене, видно, всі роки однакові..."58 (до О. П. Косач (сестри), 10 січня 1908 р., Ялта).

Приємний виняток із несприйняття побажального дискурсу, адресованого їй, Леся Українка, як свідчать листи, робила лише для сестри Ольги („Але тобі, Лілеєнько, спасибі за поздоровлення і бажання, ти ж „, Маscottе” (maлicман, амулет (франц.)), і твої слова, певне, не гинуть марно в „книзі долі"”,59 (до О. П. Косач (сестри), 25 січня 1904 р., Тбілісі)) й родини Драгоманових ( ,Пишу обом разом, бо я тепер на писання не бистра, та й листи ваші прийшли мало не в один час. Спасибі за поздоровлення і всі любі слова, може бути, факти покажуть, щц вони не даремні"60 (до Л. М. Драгоманової та Л. М. Драгоманової-Шишманової, 25 лютого 1899 р., Берлін).

Хоч для інших вона намагалася систематично надсилати святкові вітання. I навіть іноді ображалася через незнання про відзначення ювілеїв дорогих іiі серцю людей і неможливість привітати їх вчасно: „Шкода мені, мамочко, щзо я не знала, на коли був назначений ювілей Миколи Віталійовича (Лисенка. С. Б.), все ж таки хоч телеграму прислала б! Уже ж коли якась пані Грушещька од своєї тільки одної особи одважслась урочистий привіт послати, то і я могла б від себе голос подати на всеукраїнському святі! А то ж тут і більше украӥниів $\epsilon-$ Квітка з охотою зібрав би їх підписи, можна було б $і$ якусь адресу зладити. Я навіть, здається, питала якось у тебе, коли той ювілей буде, та хоч би й не питала, то все ж комітет, де були приязні і рідні люди, міг би про мене згадати... Та щзо вже тепер! Передай Миколі Віталійовичу хоч тепер мій запізнений привіт і скажи, щзо я дуже жалую про те, щзо не могла ні своєю особою, ні хоч би підписом взяти участі в його святі "“1 (до О. П. Косач (матері), 18 січня 1904 р., Тбілісі). І мабуть, як ніхто інший вона вміла тішитися пошануванням різних урочистих дат у житті їі друзів, родичів, а особливо якщо такі заходи мали рівень, достойний постаті ювілянта. Варто процитувати лишень ії міркування щодо ювілейних заходів із нагоди відзначення ювілею Михайла Драгоманова: „, 3 нетерпеливістю чекаю другої половини „,Н[ароду]”, де будуть наші адреси. Дядько був надзвичайно зворушений, читаючи про ювілейну справу. Та справді не міг він не бачити, щзо його ювілей був чимось іншим для нас усіх, ніж звичайні ювілеї з тречними промовами. Се справді було свято свідомої себе України. Шкода тільки, щзо завчасу не сповістили європейських вчених, товаришів дядька, їх привіти були б приємні для дядька і корисні для справи. Тут є і моя вина, щуо не догадалась та не дорадила кому слід, ну, щзо вже - мудрий лях по шкоді ”'62 (до М. І. Павлика, 23 лютого 1895 р., Софія).

\footnotetext{
57 Там само, т. 12 , с. 11-12.

58 Там само, с. 222.

59 Там само, с. 101-102.

60 Там само, с. 94.

${ }^{61}$ Леся Українка, Зазн. джерело, т. 12, с. 97.

${ }^{62}$ Там само, т. 10 , с. 281-282.
} 
У дні народження та іменин членів Косачівської та Драгоманівської родин Леся Українка надсилала здебільшого дуже лаконічні вітання на зразок: „„юба Лілея, я не поздоровила тебе з іменинами, бо різні стилі календарні збили з толку. Прийми се поздоровлення"б3 (до О. П. Косач (сестри), 11 червня 1902 р., Катанья). Створюється враження, що така нейтральна тональність привітань мотивована все тим же зневір'ям щодо можливості їх здійснення, а почасти й пересторогами мимохіть сказати щось не до ладу і не навмисне зашкодити адресатові (,,Милая Лілея! / Поздоровляю тебе з твоїми роковинами, а бажання ти вже сама собі придумаєш, бо я „заздрих” боюся” (до О. П. Косач (сестри), 6 червня 1900 р.. Гадяч), порівн. також: „Тебе міџно-міџно иілую, а серйозно бажати чого-небудь боюсь”"64 (до О. П. Косач (сестри), 18 січня 1898 р., Ялта). Почасти, вдаючись до узагальнених і стереотипних побажань, Леся Українка навіть спонукала адресатів наповнити побажальний контекст самим: „Любі мої мамочко і Ліля. / Пишу вам обом разом, думаючи, щяо ви вже обидві в Гадячі. Мій лист мусить прийти якраз на ваші іменини, отже, вкупі з ним прийміть мої поздоровлення і бажання всього найкращого, а яке воно, власне, оте „найкраще”, се вже віддаю на вашу волю" 65 (до О. П. Косач (матері) і О. П. Косач (сестри), 18 липня 1897 р., Ялти) (11 липня (ст. ст.) за церковним календарем день пам’яті київської княгині Ольги).

Відсутність віри в здійснення побажань, очевидно, стала однією 3 передумов того, що вона нерідко забувала про дати народжень та іменин рідних і вітала їх вже опісля (порівн.: „Нехай Рада не сердиться, щяо я ї̈ не поздоровила з іменинами, я скажу вже просто: „Ах, матушечки, и позабыла!” Все одно я ї̈ і так поздоровляю, без іменин" ${ }^{\prime 66}$ (до Л. М. Драгоманової-Шишманової, 2 жовтня 1896 р., Колодяжне) (з днем пам'яті Аріадни, що відзначається 1 жовтня); „Тільки що отримала вашого листа - таки на перший день свят! Вибачай, папа, щуо я тебе на іменини не поздоровила, се через те, щңо тут якось не можна пам'ятати завжди, яке число старого стилю приходиться на [да]ний день, та ще за 5 днів наперед. Так все одно я тебе тепер поздоровляю тричі $i$ з іменинами, $i$ з Різдвом, та вже й з Новим роком, що тут уже на иілий тиждень постаршав" "67 (до О. П. Косач (матері) і П. А. Косача, 7 січня 1903 р., Сан-Ремо). Відсутність вітань родині й друзям Леся Українка мотивувала іноді об'єктивними передумовами: зокрема незнанням знаходження адресатів: , Коли ж Ви чи хто з наших за щось на мене розсердились, то все-таки не сердьтесь аж до мовчання - адже можна і таке почуття виражати словами, хоч би й не дуже лагідними. Прошу краще лаятись, ніж мовчати, хоча не почуваю за собою нічого лайки гідного. Хіба що не поздоровила Лілю й маму 11/VII, але ж я навіть не знала, куди їм обом писати. От і переӥхала знов на початок листа!"”8 (до М. В. Кривинюка, 6 серпня 1910 р., Телаві).

Симптоматичний для характеристики такої поведінкової риси віддалений ретроспективний коментар самої адресантки в листі до матері 3 січня 1910 року з Хельвана: „От сьогодні 21/XII - день іменин папи... Як часто я забувала сей день при житті папи, а тепер з яким тяжким жалем я згадала його!.. Справді, чому я так байдужа до всяких свят тоді, коли вони могли б

\footnotetext{
63 Там само, т. 11 , с. 360.

64 Там само, с. 10.

65 Там само, с. 374.

66 Там само, с. 356.

${ }^{67}$ Леся Українка, Зазн. джерело, т. 12, с. 9.

68 Там само, с. 315-316.
} 
дати якусь радість, i чому я все святкую їх тугою?.. "69 (до О. П. Косач (матеpi), 3 січня 1910 р., Хельван).

Про власне благовістя - день народження (Леся Українка називає цей день іменинами й днем роковин, а в дитячому листі, пишучи про день народження сестри Ольги, називає його рождение) вона згадує кілька раз. Перший раз із заувагою про те, що рідні забули (!) про нього ( „Милая Лілея! / Спасибі за поздоровлення. Я сього року свої іменини дуже тихо справляла, краще сказати, ніяк. Всі про них забули, окрім дядини і Ради; вони мені подарували портpeт Гейне, се було tres a propos (дуже до речі (фр.)) "'70 (до О. П. Косач (сестри), 10, 13 квітня 1900 р., Київ), іншого разу - з нагоди свого 31-річчя (, Чудний се лист, правда? Се, може, того, щзо сьогодні „урочистий” день мойх роковин. Сьогодні я скінчила 31 рік. Сей день завжди якось неприємний, бо мимоволі оглядаюсь назад, „на путь минулу” і... зрештою, не варт розводитись на сю тему, бо все одно не поможе,"71 (до О. Ю. Кобилянської, 26 лютого 1902 р. СанРемо) і втретє - описуючи свої відчуття щодо „поважної” дати - 42-ої річниці, що попри все не навіювало на неї виразно песимістичного настрою (,,Мені дуже мило було одержати привітання від тебе $i$ від Левенятка, $і$ се мені підсолодило трохи враження від моїх 42-х роковин, щчо самі по собі не могли бути дуже приємними, бо се вже цчифра така, щзо показує не до Петра, а до Різдва. Ну, та нічого, коли минув час петрівчаних пісень, то ще, як дасть біг, поколядуємо трохи людям, поки сила"72 (до Г. М. Комарової, 3 березня 1913 р. Хельван).

Найчастотніші вітання з нагоди Різдва й Нового року нерідко обмежувалися в листах стереотипними вітаннями „, Святий вечір” і побажанням „, Святкуйте здорові” („Ну, бувай здорова, люба мамочко! Тут у нас уже попідвіконню колядують, тож можна вже сказати: „Святий вечір, добрий вечір”. Всім, хто з тобою тепер, моє вітання ${ }^{73}$ (до О. П. Косач (матері), 2 січня 1912 р., Цулукідзе); „До речі, либонь, уже час казати: святий вечір! Святкуйте здорові і мене згадайте "74 (до О. П. Косач (сестри), 27 грудня 1912 р., Хельван)") або „З Новим роком” (,Не знаю, коли сей лист до тебе дійде (боюся, щзо Д[митро] Ів[анович] на свята виїхав і лист лежатиме), але вже, певне, по Новім роиі, отже, „З Н Новим роком!'”5 (до О. П. Косач (сестри), 5 січня 1911 р., Кутаїсі). Найчастіше в новорічних вітаннях Леся Українка вдавалася до побажань щастя, послуговуючись узвичаєним виразом з Новим роком, з новим щзастям: „З Новим роком, з новим щастям! / Люба Лілічко і панове громадо, бажаю вам усім щуастя $і$ вдачі на кожній дорозі... Коли сей лист застане папу щуе в Києві, то передай йому моє поздоровлення з Новим роком ... "76 (до О. П. Косач (сестри), 18 січня 1898 р., Ялта).

Вітаючи з Великодніми святами, Леся Українка здебільшого послугувалася нейтральними вітальними фразами поздоровляю з (роковим днем) Великоднем і поздоровляю з роковим днем Великоднем (,Р. S. Поздоровляю з Великоднем тебе, папу, Микося, Зорю і Дору. Чи не було б ласкаве молоде панство написати до мене по слову хоч для рокового дня - великодня? / Моє вітання

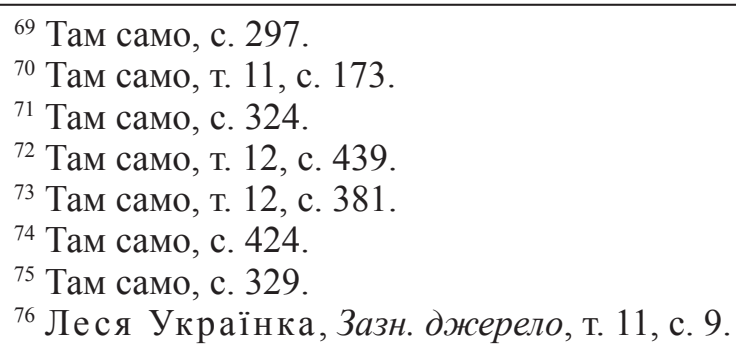


теж всім, хто мене згадає 77 (до О. П. Косач (матері), 11 квітня 1898 р., Ялта); „Поздоровляю тебе i nany i все товариство з роковим днем Великоднем!"”8 (до О. П. Косач (матері), 11 квітня 1898 р., Ялта) і стереотипним виразом Христос воскрес!

Емоційно й експресивно окреслений статус мають побажання, адресовані приятелькам Катерині Голоті та Ользі Кобилянській із виразною орієнтацією на мовноповедінкові моделі гуцулів, порівн.: „Сердечно здоровлю. Аби-сьте завжди підскакували" "79 (до К. Голоти, 19 січня 1902 р., Сан-Ремо) і „Як же мається мій хтось, мій хтосічок любий? Хтось не вірить, що хтосічок вже „ніколи не буде здоров, як горішок”, - ні, хтосічок буде, буде! От якби хтось до когось міг приїхати на Кавказ, то би хтось когось напевне викорував, хтось би міг! А може, хтось приїе?..." "80 (до О. Ю. Кобилянської, 27 серпня 1904 р., Зелений Гай).

Спостережено, що найчастіше Леся Українка вживала як елемент побажальних виразів лексему щастя відповідно до узвичаєних українських поведінкових моделей: як окрему опорну лексему ( „3 Новим роком, з новим щастям! Запізнений привіт, але ж від того він не менше щииий..."»1 (до О. Ю. Кобилянської, 30 січня, 3 лютого 1900 р., Київ); „Тільки щзо одержала листа твого від 14-го. Поздоровляю Доруню і нового швагра, щиро бажаю щастя $і$ вірю в сповнення сього бажання - вони добрана пара!"82 (до О. П. Косач (матері), 2, 3 травня 1912 р., Кутаїсі)), так і в поєднанні з іншими, здебільшого 3 лексемою здоров'я (порівн.: „З Новим роком! / Милая бабушка, поздоровляю Вас [з різдвяними] святами і з наступаючим Новим [роком. Бажаю] Вам щастя, здоров'я $і$ всього найкращого "вз (до С. І. Драгоманової, початок січня 1890 р., Колодяжне); ,Щастя й здоров'я Вам ”в4 (до Н. К. Кибальчич, червень - липень 1908 р., Свпаторія). Характеристично, що Леся Українка в листі до Михайла Павлика в січні 1892 року зізнавалася, що сама не дуже виразно окреслює для себе значеннєвий вимір цього поняття (, $P . S$. У У нас кажуть: „, 3 Новим роком, з новим щастям!” Але що таке щастя? Для мене ся ідея не стоӥть ясно перед очима" "85) i, зрештою, вона й не вірила, очевидно, в його реальність, порівн.: „Любий дядьку! / Поздоровляю Вас і всіх наших з Новим роком, сказала б з новим щастям, та я щось не вірю в щастя, отже, бажаю здоров'я та трошки більше спокою і радощів" "д6 (до М. П. Драгоманова, 17 січня 1894 р., Київ). Підгрунтя таких міркування дозволяє декодувати коментар із побажання Осипові Маковею напередодні Різдва 1894 року: „А тепер поздоровляю Вас з близькими святками і бажаю Вам щастя, здоров'я та оптимізму (з ним i само щастя мусить прийти)"'87 (до О. І. Маковея, 24 грудня 1893 р., Київ). А отже, логічною передумовою щастя Леся Українка вважала здоров'я та оптимізм і розглядала їх як взаємопов'язані складові.

\footnotetext{
77 Tам само, c. 40.

78 Там само, с. 42.

79 Там само, с. 315.

${ }^{80}$ Там само, т. 12 , с. 110.

${ }^{81}$ Там само, т. 11 , с. 159.

82 Там само, т. 12, с. 392.

${ }^{83}$ Там само, т. 10 , с. 46.

${ }^{84}$ Там само, т. 12 , с. 249.

85 Там само, т. 10 , с. 300.

${ }^{86}$ Там само, с. 201.

87 Там само, с. 189.
} 
Іноді, не встигаючи привітати всіх дорогих її серцю людей зі святами, вона, вибачаючись, зауважувала, що для неї і будень не є перешкодою для побажань, головне - „сила”, тобто реалізація іiі побажань: „Але я перед святами саме вибиралася з Києва - додому приїхали ми в середині страсного тижня, - а на свята щуе не ввійшла настільки в колію життя, щуоб засісти за писання листів. Так я Вас і з Великоднем не поздоровила, але все одно я $\boldsymbol{i}$ без свята завжнд бажсаю Вам всього найкращого, якби жс тільки мої бажсання мали яку-небудь силу!"88 (до А. С. Макарової, 14 травня 1894 р., Колодяжне).

Лексема гаразд як одна з опорних у семантичній структурі побажань відтворює також типову поведінкову українську модель: ,, Бажаю Вам сили, здоров'я i всіх гараздів"89 (до Ф. М. Колесси, 18 березня 1913 р., Хельван). Паралельно Леся Українка актуалізує архаїчний семантичний варіант цього ж виразу здоровлю всім гараздом: „,Оксаночку, хоч пізно, „здоровлю усім гараздом” і радуюсь, щзо ї̈ діла з консерваторією та й здоров'ям добрі"'90 (до родини Косачів, 13 квітня 1909 р., Телаві) (до речі, лапки засвідчують інтекстовий характер цього вітання і дають можливість припустити, що саме цей вираз належав до мовноповедінкового виміру родинного спілкування Косачів). Ці вирази, хоч і відтворюють традиційну поведінку українців, однак не фіксовані лексикографічними джерелами української мови в цій функції, незважаючи на те, що одне зі значень узвичаєно подається як синонім до щзастя і благополуччя або добра, щзастя й благополуччя. В етикетній функції фіксовано лише вираз майтеся гаразд, що узуально ,уживається як побажання бути здоровим і щасливим, жити у добрі та злагоді, хай буде все добре"91.

Народно-розмовним колоритом позначений стереотипний побажальний вираз здоров'я в хату: „Коли б там Вам швидше здоров'я в хату!'92 (до Н. К. Кибальчич, 27 березня 1911 р., Хельван).

Крім згаданих, в побажальних виразах репрезентована також опорна лексема добро (,Дякуємо обоє за поздоровлення $і$ бажаємо всякого добра",9з (до Ф. М. Колесси, 9 січня 1909 р., Тбілісі)),

Вагомим елементом побажальної поведінки адресантки можна вважати також постійну актуалізацію 'побажання' в узвичаєних епістолярних прощаннях будь /-те здоров /-a, -i (-здоровеньк /-a, -i) ( „, Будь здорова, любая, і Михалюньо нехай там одужує швидше "94 (до О. П. Косач сестри), 16 травня 1911 р., Київ); „Будьте мені здоровенькі"95 (до О. Ю. Кобилянської, 9 червня 1911 р., Севастополь); , Нy, $\boldsymbol{i}$ будьте здорові, дорогий товаришу”'96 (до А. Ю. Кримського, 6 червня 1012 р., Кутаїсі).

Іноді такі стереотипні вирази зазнають структурно-семантичних трансформацій за рахунок ускладнення повсякденного прощально-побажального дискурсу додатковими лексемами ( „Будьте здорові $і$ музам милі”97 (до Ф. П. Петруненка, липень 1911 р., Кутаїсі).

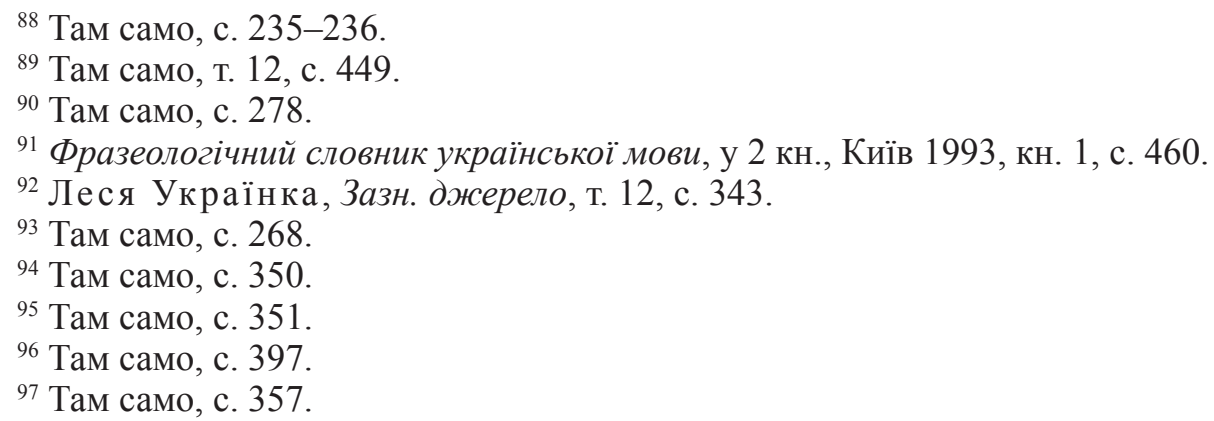


Менш продуктивні в привітальних формулах лексеми повіншувати, віншувати, віншування, повіншування фіксовані в листах до Івана Франка, Михайла Павлика, Ольги Кобилянської та сестри Ольги. Лексеми цього деривативного ряду, як відомо, привнесені в нашу мовноповедінкову традицію з середньоверхньонімецької мови через посередництво польської й узвичаєно вживані як опорні у вітальних контекстах ${ }^{98}$. Порівняно 3 іншими лексемами цього ж синонімічного ряду, похідними від твірної основи вim-, ці опорні лексеми надають конототивних відтінків, особливої урочистості висловлень і підкресленої шанобливості до адресата, порівн.: „Хоч трошки завчасне, але вже при сій „оказіі”, повіншую Вас з юбілеєм, шкода тільки, щзо не можу тепер відповідного стилю добрати, бо дуже спішуся. Була б я рада, коли б могла сама прибути на Ваше свято, може, тоді щире стискання руки замінило б слова. Та щзо там стиль! Ви знаєте, щзо я щзиро поважаю Вас і Ваш талан, а знаючи тяжку долю українського поета, „рада б неба прихилити”, аби та доля поліпшала. Щасти Вам боже на кождій дорозі!"99 (до І. Я. Франка, 21 жовтня 1898 р., Київ). Зауважмо, що і в цьому вітанні Леся Українка акцентує увагу на брак , відповідного (поздоровного. - С. Б.) стилю”, а головне, що, на її переконання, невербальна комунікація (один-єдиний жест!) здатна передати значно повніше семантику.

Про неодмінний атрибут свят - подарунки - Леся Українка згадує неодноразово в листах до різних адресатів, здебільшого до родини. Це зокрема дарунки на Різдво чи на день народження від бабусі, Драгоманових, батьків, на ювілей із нагоди літературної діяльності Михайла Драгоманова. Предмет дарування, залежно від особи того, кому дарували, різний: дітям - узвичаєно іграшки, книги, одяг (напр.: „Вчора були Тамарині іменини, $i$ nana iй подарив повозочку з лопаткою і вилками, котрими вона дуже втішається"100 (до С. І. Драгоманової, 14 травня 1884 р., Колодяжне); „Позавчора було Лілі рождение, і я ій подарила краски, а мама комод для кукол"101 (до Є. І. Драгоманової, 9 червня 1884 р., Колодяжне) тощо.

Особливу увагу приділяла Леся Українка дарункам для племінників, про що свідчить зокрема один із їі листів до сестри Ольги: „, Михальові посилаю поясок ширшенький, а вужченький - маленькій Оксаночці і їй же три брелочки vie, santé, forse (життя, здоров'я, сила (франц.). - Ред.), - я давно хтіла їх послати, та боялась, щзо в листі пропадуть. Ти ж, певне, будеш бачити обох Оксан, то почілуй їх за мене, і нехай маленька носить мої „талісмани” або почепить на люлю”"102 (до О. П. Косач (сестри), 2 (1, 27 жовтня 1911 р., Цулукідзе).

Незвичним для сучасних подарункових традицій може видатися більш ніж скромний, як на сучасне сприйняття, Лесин дарунок на іменини мамі й сестрі Ользі: ,Люба Олесю! / Поздоровляю тебе і мамочку-голубочку з іменинами, бажаю вам щцастя, долі і слави по сей і по той бік кордону. Не погордуйте прийняти від мене в подарунок коробочку з сірничками, розділіться ними, як самі знаєте, на щзось більшого мені годі спромогтися. Шкода, щуо я не могла їх купити до виїзду Миші, то може б вони скоріш приїхали, як тепер по сих проклятих кримських поштах. Отже, вибачте, щзо моє поздоровлення і сірники прийдуть, може, через тиждень після іменин, але зате, може, воно цікавіше вийде. Пишучи той лист, щьо послала з Мишею, я так була заспішена $і$ зажу-

${ }^{98}$ Етимологічний словник української мови, в 7 тт., Київ 1982, т. 1, с. 401.

99 Леся Українка, Зазн. джерело, т. 11, с. 74.

100 Там само, т. 10 , с. 15.

101 Там само, с. 16.

102 Там само, т. 12 , с. 390. 
рена, щзо навіть поздоровити вас забулася,-ви, знаючи теє, мені вибачите "'103 (до О. П. Косач (сестри), 23 липня 1891 р., Свпаторія).

Отже, листовні тексти Лесі Українки містять цілий спектр найменувань концепту свято й засвідчують їі особливе ставлення до свят і святкувань, мотивоване різними особистісними та екстралінгвальними чинниками, що позначилися зокрема й на лаконічності побажально-привітальних контекстів, оріснтованих в основному на традиції святкового поведінкового дискурсу українців, мовна репрезентація якого представлена значною мірою стереотипними етикетними виразами, частково - їхніми трансформаціями. Факультативно Леся Українка вдавалася до індивідуально увиразненого мовного вияву побажань і привітань, що стилістично увиразнюють їі епістолярну поведінку.

${ }^{103}$ Там само, т. 10, с. 97. 